\title{
On estimating Weibull modulus by moments and maximum likelihood methods
}

\author{
Murat Tiryakioğlu
}

Published online: 9 October 2007

(C) Springer Science+Business Media, LLC 2007

\section{Erratum to: J Mater Sci}

DOI 10.1007/s10853-007-2095-7

There is a misprint in "On estimating Weibull modulus by moments and maximum likelihood methods" by Dr. Murat Tiryakioğlu, doi 10.1007/s10853-007-2095-7.

Figure 5 in the text shows the same data as in Fig. 3, which shows the standard deviation for the moments method. The standard deviation data for the maximum likelihood method was mistakenly replaced with those shown in Fig. 3. The correct figure is as follows:

The online version of the original article can be found under doi: 10.1007/s10853-007-2095-7.

M. Tiryakioğlu (ه)

Department of Engineering, Robert Morris University, 6000

University Boulevard, Moon Township, PA 15108, USA

e-mail: tiryakioglu@rmu.edu 